\title{
Sustainable Development of the Tourism Sector in the Palestinian Economy
}

\author{
Khalid Mohammad Hasan Sweis ${ }^{1}$, Tamer Bahjat Sabri ${ }^{1} \&$ Issam N. Ayyash ${ }^{1}$ \\ ${ }^{1}$ Department of Computerized Financing and Banking, The College of Business and Economics, Palestine Technical \\ University, Kadoorie, Tulkarm, Palestine \\ Correspondence: Dr. Issam N. Ayyash, Assistant Professor, Department of Computerized Financing and Banking, \\ The College of Business and Economics, Palestine Technical University, Kadoorie, Tulkarm, Palestine. E-mail: \\ e.ayash@ptuk.edu.ps
}

Received: April 18, 2020

Accepted: July 21, 2020

Online Published: September 3, 2020

doi:10.5430/rwe.v11n5p220

URL: https://doi.org/10.5430/rwe.v11n5p220

\begin{abstract}
The study aimed to identify the role of sustainable development of tourism in the Palestinian economy; it also aimed at identifying the various points of view of the study respondents mainly those who are involved in the tourism sector as well as other sectors. The researchers adopted an analytical descriptive approach using a questionnaire that was distributed to the sample of the study $(n=313)$. The results of the study showed that about $88 \%$ of the respondents called for the need for further investments in the Palestinian tourism sector. One of the most important recommendations is the need to expand the scope of promoting tourism, increase services and improve the infrastructure of the Palestinian tourism sector.
\end{abstract}

Keywords: sustainable development, the Palestinian economy, tourism

JEL Classification: A10; A13; B22

\section{Introduction}

The annual growth in the tourism sector is up to $7.7 \%$. This makes tourism one of the most profitable economic activities for countries. Two questions about tourism are being raised by the private sector and the government. First, how to remove the complexities of borders to develop the tourism industry, and second, how to attract investment into the tourism sector (Zurub et al., 2015).

Tourism is also one of the most important socio-economic sectors in our time. Globally, tourism creates many job opportunities and contributes to about $10 \%$ of the world's gross domestic product (Hrubcova et al., 2016). It has a great economic impact on sales, profits, jobs, and tax revenues. On the other hand, tourism has direct effects on restaurants, transportation, amusements and retail (Ardahaey, 2011).

Palestine has a unique and varied tourism wealth. It is the cradle of the three heavenly religions (Islam, Christianity and Judaism); it is also cradle of and the center for many civilizations that left clear marks on the human heritage. Despite its small size, it is characterized by a geographical richness in biodiversity and climate variation which acts as an attraction for leisure activities and holiday tourism. However, Palestine has been under the Israeli occupation since 1967; this has deprived it of and prevented it from taking full advantage of the exploitation of its precious various tourist resources (Al-Falah, 2012).

Nevertheless, the Israeli occupation authorities have taken control of the most prominent tourist attractions especially those located in the city of Jerusalem, the Dead Sea and the Jordan Valley. They also deprived the Palestinians from making use of these resources and allowed the Israeli tourism companies to exploit these attractions and market them as Israeli locations and/or tourist facilities.

On the other hand, the Israeli authorities have continued to impose restrictions and limit the opportunities for making use and exploiting the tourist resources that have fallen under the jurisdiction of the Palestinian National Authority after its establishment in 1994, especially in the city of Bethlehem, Gaza, Nablus and all other Palestinian cities and villages. 
The tourism industry in Palestine has experienced several setbacks as a result of the conflict initiated by the Israeli occupation during many stages. The Palestinian - Israeli conflict has made tourism a volatile activity and limited its development and utilization. It is worth mentioning that among the obstacles laid before tourism are the wars in 1948, 1956, 1967, 1973, and 1982 which were initiated and waged by the Israeli occupation to impose new facts on the ground. The first Intifada in 1987 and the second (Al-Aqsa) Intifada in 2002 have been considered as major obstacles to the development and boom of this industry; the two uprisings resulted in many destructive effects that have prevented the arrival of tourists to the region, in general, and Palestine in particular. These events have had an impact on the systems of neighboring countries and their peoples; several events took place in the neighboring countries in solidarity with the Palestinian right in their quest for salvation from the Israeli injustice. Consequently, the tourism sector was negatively affected. Lack of security has resulted in a grand decline in this vital sector.

Since 1967, Palestinian tourism has suffered a tremendous setback; Israel has taken over Palestinian tourist capabilities and has changed Jordanian and Egyptian laws and regulations by military orders that only serve its interests and satisfies its needs. This has led to the decline and disappearance of the tourism sector and the lack of investment in it. The Israeli occupation authorities have taken control of the borders and crossings with Palestine neighboring countries; they have also directly controlled the process of entry and exit into and out of the Palestinian territories which prevented the free flow of tourist traffic into the Palestinian lands.

\section{Statement of the Problem}

The tourism sector was and has still been of great importance to most countries in the world. In Palestine, this sector has a historical and religious importance to the extent that it can be invested economically. However, this sector has not been developed or invested despite its importance; there was a clear weakness in the economic structure of the tourism sector despite the many elements of success including site or location, civilization, history, and existence of the three heavenly religions. For example, Bethlehem is holy city for Christians as it is the birthplace of Jesus Christ, peace be upon him. Jerusalem is holy for all religions mainly Islam due to the existence of Al-Aqsa Mosque which represents the third of the two holy sites, and the first Qibla for Muslims. Therefore, the researchers have raised the following main question:

What is the impact of the sustainable development of the tourism sector in the Palestinian economy?

\section{Objectives of the Study}

The researchers sought to achieve the following objectives:

Identify the role of sustainable tourism development in the Palestinian economy.

Analyze the opinions of those who are related to the tourism sector including managers of tourism offices and their owners, restaurant owners, and shop owners, hand-held workshops directors and supervisors so that they discuss them about the main barriers.

Identify the extent of the Palestinian government's role in assisting investors in the tourism sector and the extent of their response to them.

Provide a set of recommendations for improving and developing the Palestinian tourism sector.

\section{Importance of the Study}

The current study was deemed significant for the following considerations:

The wealth of the Palestinian territories in religious tourism sites that have not been properly invested so far (for example: the Al-Aqsa Mosque for Muslims in Jerusalem, the Church of the Nativity, the birthplace of Jesus Christ in Bethlehem, and the Dead Sea water and its health importance in Jericho).

It is very significant for the government to direct investors to the tourism sector because of its material and moral benefits as well as the need to improve the balance of payments.

It is crucially important to revitalize the tourism sector as it may reduce unemployment and create job opportunities for many Palestinians.

\section{The Hypothesis of the Study}

There were no statistically significant differences at the level of significance $(\alpha=0.05)$ in the sustainable development of the tourism sector in the Palestinian economy that may be attributed to academic qualification, gender, field of work, years of experience, capital, number of workers, governorate. 


\section{Review of Literature - Previous Studies}

Gozgor \& Ongan (2017) carried out a study to examine the relationship between tourist uncertainty and expenditure in the United States for the period 1998-2015. The researchers used unit root and counteraction tests to analyze the data. The study results showed that the high level of uncertainty about economic policy leads to a decline in tourism spending in the long run.

Isik et al. (2017) conducted a study to investigate the relationship between tourism, renewable energy and economic growth in the USA, France, Germany and Spain using the panel granger causality model. The study results showed that the relationship between tourism and economic growth is interrelated in some countries such as Germany and that there is a causal relationship between renewable energy and economic growth

On the other hand, Paramati et al. (2016) did a research that aimed to examine the relationship between tourism and economic growth in developing and developed countries using robust panel econometric techniques. The results showed that tourism has a positive and statistically significant impact on economic growth in developing and developed countries.

Hrubcova et al. (2016) carried out a study to prove that tourism is one of the largest industries in the world. The study aimed to analyze the economic effects of tourism for a group of developed countries; the researchers also aimed at discussing the pros and cons of tourism by the use of cluster analysis. The study results showed that tourism has a positive impact on most economies of developed countries. The researchers of the study recommended that government should consider the effective participation of local communities and the reduction of leakage among these communities due to the fact that they play a significant role in this area.

Shiji (2016) stated that tourism is one of the nine major areas of employment and it contributes about $10 \%$ to the world GDP. The researcher aimed at measuring the economic impact of tourism on the economy in India as well as finding several measures including general equilibria model, but this study will use the method of visitor spending method. The researchers found that Indian tourism has a positive impact on the economy in terms of providing job opportunities and foreign exchange. The government, the private sector and voluntary organizations have become active players in the tourism process in India.

Zurub et al. (2015) carried out a study that aimed at finding out the relationship between the impact of tourism on the economies of emerging countries and European markets. The results showed that there is no doubt that tourism has a significant impact on the economy and infrastructure of these countries.

\section{Method and Procedures}

This part includes a description of the methods and procedures used by the researchers in defining the study population and the study sample; it also includes a complete description and explanation of the steps and practical procedures are followed in building the study tool and describing. The researchers then clarify the procedures maintaining the validity and reliability of the study tool as well as the plan of the study and its variables. The researchers also refer to the types of statistical tests used in studying the variables that relate to sustainable development and its impact on the Tourism sector in the Palestinian economy.

\subsection{The Study Sample}

The sample of the study $(n=363)$ represented $5 \%$ of the total number of registered merchants in the Chamber of Commerce in both Tulkarm and Jenin Governorates $(n=7,362)$. They work in various fields. After excluding the invalid questionnaires, the final study sample was (313); they were valid questionnaires used in the analysis. In selecting the sample, the researchers took care of the normal distribution based on scientific qualification, sex, field of work, years of experience, capital in US dollars, number of labor force, and governorates. The following table describes the study sample based on its independent variables.

Table 1. Distribution of the sample of the study based on its basic variables

\begin{tabular}{cccc}
\hline Variable & Category & Frequency & Percentage \\
\hline \multirow{3}{*}{ Qualification } & High School or less & 77 & 24.6 \\
\cline { 2 - 4 } & Diploma & 43 & 13.7 \\
\cline { 2 - 4 } & Bachelor & 168 & 53.7 \\
\cline { 2 - 4 } & Master's & 25 & 8.0 \\
\hline
\end{tabular}




\begin{tabular}{|c|c|c|c|}
\hline & Total & 313 & 100.0 \\
\hline \multirow{3}{*}{ Sex } & Male & 267 & 85.3 \\
\hline & Female & 46 & 14.7 \\
\hline & Total & 313 & 100.0 \\
\hline \multirow{5}{*}{ Employment } & Tourism & 56 & 17.9 \\
\hline & Trade & 131 & 41.9 \\
\hline & Industry & 63 & 20.1 \\
\hline & Agriculture & 63 & 20.1 \\
\hline & Total & 313 & 100.0 \\
\hline \multirow{5}{*}{ Years of Experience } & Less than 5 years & 80 & 25.6 \\
\hline & $6-10$ years & 99 & 31.6 \\
\hline & $11-15$ years & 62 & 19.8 \\
\hline & More than 15 years & 72 & 23.0 \\
\hline & Total & 313 & 100.0 \\
\hline \multirow{6}{*}{ Capital in USD } & Less than 50000 & 154 & 49.2 \\
\hline & $100000-50001$ & 87 & 27.8 \\
\hline & $100001-150000$ & 37 & 11.8 \\
\hline & $150001-200000$ & 13 & 4.2 \\
\hline & More than 200,000 & 22 & 7.0 \\
\hline & Total & 313 & 100.0 \\
\hline \multirow{6}{*}{$\begin{array}{c}\text { Number of manpower } \\
\text { (Labor force) }\end{array}$} & Less than 10 & 177 & 56.5 \\
\hline & $10-20$ & 81 & 25.9 \\
\hline & $21-30$ & 38 & 12.1 \\
\hline & $31-40$ & 7 & 2.2 \\
\hline & More than 40 & 10 & 3.2 \\
\hline & Total & 313 & 100.0 \\
\hline \multirow{3}{*}{ Governorate } & Tulkarm & 177 & 56.5 \\
\hline & Jenin & 136 & 43.5 \\
\hline & Total & 313 & 100.0 \\
\hline
\end{tabular}

\subsection{Study Tool}

The researchers developed a special questionnaire to study the impact of sustainable development of the tourism sector on the Palestinian economy. The study tool included two main parts: First, personal demographic data relating to the academic qualification, gender, field of work, years of experience, capital in dollars, number of manpower, and governorate. Second, all the paragraphs or items of the questionnaire $(n=27)$.

\subsection{Reliability of the Study Tool}

\subsubsection{Reliability Factor}

Reliability is defined as accuracy in estimating the real mark of the individual on the attribute measured in the study. In other words, it is a measure of the stability or consistency of test scores. You can also think of it as the ability for a test or research findings to be repeatable. A reliability coefficient is a measure of how well a test measures achievement. It is the proportion of variance in observed scores (i.e. scores on the test) attributable to true scores. To measure the reliability coefficient of the study tool used, the researchers decided to use the Cronbach Alpha; it was found to be (0.846) on all paragraphs of the questionnaire; such a value is found to be suitable for statistical analysis and for the purpose of study as well.

\subsection{Study Procedures}

The researchers conducted the following procedures: 
Qualify the questionnaire in its final form after it was presented to five specialized arbitrators, and the amendments were made accordingly.

Identify the sample members of the study to include as many sectors and stakeholders as possible.

Distribute the questionnaire to the members of the sample of the study, collect valid questionnaires, unloaded the data in special tables for processing, and exclude invalid questionnaires from analysis.

\subsection{Design of the Study}

The researchers used the descriptive approach and analytical method to study the relationship between the variables of the study, collected relevant information and then used statistical analyses to examine the hypotheses in order to interpret the results. The study included the following variables:

\section{Independent Variables}

The scientific qualification; it has four levels.

Sex variable and it has two levels.

Field of work and this variable has four levels.

Years of experience and it has four levels.

Capital and it has five levels.

Number of labor force and it has five levels.

Governorates and it has two levels.

\section{Dependent Variables}

The following variables were used to respond to the paragraphs/items of the questionnaire related to the study of the impact of sustainable development of the tourism sector on the Palestinian economy. In order to process the data, the SPSS program was adopted using the following tests:

Frequencies and percentages

Means (mathematical averages)

One-Way Analysis of Variance (ANOVA)

Cronbach alpha coefficient to calculate the coefficient of reliability

\subsection{Study Results}

\subsubsection{Statistical Analysis and Testing of Statistical Hypotheses}

This section introduces the answer to the hypotheses of the study and its statistical examination using the statistical packages for social sciences (SPSS). Here are the main results of the study. Results of the main study question:

The main objective of the current study was to answer the main question of the study, i.e.

"How much does sustainable development contribute to the tourism sector in the Palestinian economy? To answer this question, means (arithmetic averages) and percentages were calculated; the results are shown in the tables (2-6) below.

Table 2. Means and percentages of the field of the potential investment in tourist areas

\begin{tabular}{clcc}
\hline $\begin{array}{c}\text { Number } \\
\text { of item in the } \\
\text { questionnaire }\end{array}$ & \multicolumn{1}{c}{ Item } & Means & Percentages \\
\hline 6 & $\begin{array}{l}\text { The West Bank areas need more investment in the tourism } \\
\text { sector }\end{array}$ & 4.4153 & 88.306 \\
\hline 7 & $\begin{array}{l}\text { There are many tourist areas in Palestine that are not well } \\
\text { invested }\end{array}$ & 4.3514 & 87.028 \\
\hline 3 & $\begin{array}{l}\text { There are many companies providing tourist guidance } \\
\text { services }\end{array}$ & 3.5272 & 70.544 \\
\hline 1 & The Government provides and offers motivations and & 3.4281 & 68.562 \\
\hline
\end{tabular}




\begin{tabular}{clcc}
\hline \multicolumn{5}{l}{ concessions to the investor in the tourism sector } & & \\
\hline 5 & $\begin{array}{l}\text { The government encourages and promotes investment in } \\
\text { the tourism sector by issuing laws and legislations that } \\
\text { encourage so }\end{array}$ & 3.4026 & 68.052 \\
\hline 4 & $\begin{array}{l}\text { The government is directing new investors in the tourism } \\
\text { sector to areas that the tourism sector lacks }\end{array}$ & 3.3259 & 66.518 \\
\hline 2 & $\begin{array}{l}\text { The government advises investors to prepare research and } \\
\text { feasibility studies for future tourism projects }\end{array}$ & 3.3067 & 66.134 \\
\hline 8 & $\begin{array}{l}\text { I think tourism companies are reserving part of their profits } \\
\text { for research and development }\end{array}$ & 3.1438 & 62.876 \\
\hline & $\quad$ Total degree & 3.6126 & 72.252 \\
\hline
\end{tabular}

The results of Table 2 above indicate that $88.3 \%$ of the respondents said that the territories/areas of the West Bank need more investment in the tourism sector. The results also indicate that about $63 \%$ of the respondents believe that tourism companies should reserve part of their profits for research and development. Furthermore, the results show that about $66 \%$ of the respondents believe that the government should direct new investors in the tourism sector towards areas that the tourism sector lacks. The government should also encourage investment in the tourism sector by issuing laws and legislations that encourage this. In general, $72 \%$ the sample shows that there is no possibility of investment in tourist areas.

Table 3. Means and percentages of the promotional quality field

\begin{tabular}{clcc}
\hline $\begin{array}{c}\text { Number } \\
\text { of item in the } \\
\text { questionnaire }\end{array}$ & \multicolumn{1}{c}{ Item } & Means & Percentages \\
\hline 3 & $\begin{array}{l}\text { The Internet is used as a means of marketing tourism } \\
\text { services }\end{array}$ & 4.4153 & 81.598 \\
\hline 2 & $\begin{array}{l}\text { The media plays a big role in the definition of Palestinian } \\
\text { tourism }\end{array}$ & 4.3514 & 75.654 \\
\hline 1 & $\begin{array}{l}\text { The Ministry of Tourism is keen to raise the quality of } \\
\text { tourism services to the international level }\end{array}$ & 3.5272 & 71.374 \\
\hline 5 & $\begin{array}{l}\text { The State emphasizes the establishment of a distinctive } \\
\text { brand for each heritage product }\end{array}$ & 3.4281 & 70.224 \\
\hline 4 & $\begin{array}{l}\text { The Ministry of Tourism is working on the preparation of } \\
\text { booklets and publications on museums and antiquities of } \\
\text { the country }\end{array}$ & 3.4026 & 67.86 \\
\hline 6 & $\begin{array}{l}\text { The prices of tourist services in Palestine are cheap } \\
\text { compared to those in neighboring countries }\end{array}$ & 3.3259 & 66.71 \\
\hline & $\quad$ Total degree & 3.6126 & 3.6126 \\
\hline
\end{tabular}

The results of Table 3 indicate that $81.6 \%$ of the respondents believe that the Internet is used as a means of marketing tourist services while $66.7 \%$ of the respondents said that the prices of tourist services in Palestine are low compared to those in neighboring countries. The results also show that $71 \%$ the sample stated that the Ministry of Tourism is keen to raise the quality of tourism services to raise the international level in general; the researchers also found that $72.24 \%$ of respondents believe that the government should spare no efforts to promote tourism services available at high quality. 
Table 4. Means and percentages of the field of general tourism services

\begin{tabular}{cllc}
\hline $\begin{array}{c}\text { Number } \\
\text { of item in the } \\
\text { questionnaire }\end{array}$ & \multicolumn{1}{c}{ Item } & Means & Percentages \\
\hline 6 & $\begin{array}{l}\text { The concerned authorities are following and monitoring the } \\
\text { implementation of security and safety measures in tourist } \\
\text { facilities }\end{array}$ & 3.5144 & 70.288 \\
\hline 7 & Transportation is available for the tourism sector & 3.3514 & 67.028 \\
\hline 4 & $\begin{array}{l}\text { There are centers to provide extension services for those } \\
\text { who need it permanently }\end{array}$ & 3.2716 & 65.432 \\
\hline 5 & $\begin{array}{l}\text { The Ministry of Labor is keen to monitor the situation of } \\
\text { workers in the tourism sector }\end{array}$ & 3.2684 & 65.368 \\
\hline 2 & $\begin{array}{l}\text { Tourism sector projects provide all the services needed by } \\
\text { foreign tourists }\end{array}$ & 3.1725 & 63.45 \\
\hline 1 & $\begin{array}{l}\text { The Palestinian tourism sector is characterized by an } \\
\text { infrastructure capable of absorbing domestic and foreign } \\
\text { tourism }\end{array}$ & The tourist spots are clean & 3.0096 \\
\hline 3 & Total degree & 2.9968 & 59.192 \\
\hline
\end{tabular}

It is clear from the results of Table 4 that $70.3 \%$ of the respondents believed that the concerned authorities should implement the security and safety procedures in the tourist facilities, while about $60 \%$ of the respondents saw that the tourist sites are clean and that the Palestinian tourism sector is characterized by a capable infrastructure that could absorb the internal and external tourism. On the other hand, about $65 \%$ of the sample stated that there must be enough centers that could provide extension services for those who need it on a permanent basis and the Ministry of Labor is keen to follow and observe carefully the conditions of workers in the tourism sector. In general, $64.7 \%$ of respondents indicated that public services are available for tourism.

Table 5. Means and percentages of the scope of the Israeli occupation obstacles

\begin{tabular}{clcc}
\hline $\begin{array}{c}\text { Number } \\
\text { of item }\end{array}$ & \multicolumn{1}{c}{ Item } & Means & Percentages \\
\hline 5 & $\begin{array}{l}\text { The Israeli policies at the checkpoints have a negative } \\
\text { impact on the tourism movement in Palestine }\end{array}$ & 4.5016 & 90.032 \\
\hline 4 & $\begin{array}{l}\text { Palestinian tourism is closely related to the prevailing } \\
\text { security conditions in Palestine }\end{array}$ & 4.4537 & 89.074 \\
\hline 3 & $\begin{array}{l}\text { The Israeli occupation forces are targeting the tourist } \\
\text { infrastructure of the State of Palestine }\end{array}$ & 4.3514 & 77.028 \\
\hline 2 & $\begin{array}{l}\text { A tourist can enter any place in the areas under Palestinian } \\
\text { control if he/she is authorized by Israel }\end{array}$ & 3.8754 & 698.648 \\
\hline 1 & $\begin{array}{l}\text { The Palestinian Authority does not benefit from tourists who } \\
\text { attend an Israeli office to visit Palestinian areas }\end{array}$ & 3.4824 & 90.032 \\
\hline
\end{tabular}

It is clear from the results of Table 5 that $90 \%$ of the respondents believed that Israeli policies at the checkpoints negatively affect the tourism movement in Palestine while $69.6 \%$ of the respondents believed that the Palestinian Authority does not benefit from tourists who attend an Israeli office to visit the Palestinian areas. Furthermore, $87 \%$ of the respondents indicated that the Israeli occupation forces targeted the tourist infrastructure of the State of Palestine. In general, $82.66 \%$ of respondents indicated that there are obstacles to tourism in Palestine caused by Israeli occupation. 
Table 6. Means and percentages of the scope of the Israeli occupation obstacles

\begin{tabular}{llcc}
\hline Number & \multicolumn{1}{c}{ Domain } & Means & Percentages \\
& & & \\
\hline 1 & The possibility of investing in tourism & 3.6126 & 72.252 \\
\hline 2 & Promotional quality & 3.6118 & 72.236 \\
\hline 3 & General Services for Tourism & 3.2332 & 64.664 \\
\hline 4 & The obstacles caused by the Israeli occupation & 4.1329 & 82.658 \\
\hline & Total degree & 3.6476 & 72.952 \\
\hline
\end{tabular}

\section{Test Hypotheses}

There are no statistically significant differences at the level of significance $(\alpha=0.05)$ in the sustainable development of the tourism sector in the Palestinian economy attributed to the variable of scientific qualification

In order to test this hypothesis, the arithmetical averages (means) and standard deviations were calculated in the sustainable development of the tourism sector in the Palestinian economy based on scientific qualification. These results showed that there are differences in the means in the sustainable development of the tourism sector in the Palestinian economy. To test whether these differences were statistically significant, the researchers used a one-way variance analysis ANOVA and the results are shown in Table 7 below.

Table 7. Results of the one-way analysis of variance for the differences between the means in the sustainable development of the tourism sector in the Palestinian economy based on scientific qualification

\begin{tabular}{|c|c|c|c|c|c|c|}
\hline Variable & Source of variation & $\begin{array}{l}\text { Degrees of } \\
\text { freedom }\end{array}$ & $\begin{array}{l}\text { Differences } \\
\text { squared }\end{array}$ & $\begin{array}{l}\text { Standard } \\
\text { deviation }\end{array}$ & $\begin{array}{l}\mathrm{F} \text {-test } \\
\text { value }\end{array}$ & $\begin{array}{l}\text { P-value } \\
\text { (sig.) }\end{array}$ \\
\hline \multirow{3}{*}{$\begin{array}{l}\text { The possibility of } \\
\text { investment in } \\
\text { political aspects }\end{array}$} & Between groups & 3 & 1.657 & .552 & \multirow{3}{*}{1.550} & \multirow{3}{*}{.201} \\
\hline & Within groups & 309 & 110.092 & .356 & & \\
\hline & Total & 312 & 111.749 & & & \\
\hline \multirow{3}{*}{$\begin{array}{l}\text { Promotional } \\
\text { quality }\end{array}$} & Between groups & 3 & .229 & .076 & \multirow{3}{*}{.180} & \multirow{3}{*}{.910} \\
\hline & Within groups & 309 & 131.468 & .425 & & \\
\hline & Total & 312 & 131.697 & & & \\
\hline \multirow{3}{*}{$\begin{array}{l}\text { General Services } \\
\text { for Tourism }\end{array}$} & Between groups & 3 & .563 & .188 & \multirow{3}{*}{.349} & \multirow{3}{*}{.790} \\
\hline & Within groups & 309 & 166.005 & .537 & & \\
\hline & Total & 312 & 166.568 & & & \\
\hline \multirow{3}{*}{$\begin{array}{l}\text { The obstacles } \\
\text { caused by the } \\
\text { Israeli occupation }\end{array}$} & Between groups & 3 & .936 & .312 & \multirow{3}{*}{.742} & \multirow{3}{*}{.528} \\
\hline & Within groups & 309 & 130.015 & .421 & & \\
\hline & Total & 312 & 130.951 & & & \\
\hline \multirow[t]{3}{*}{ Total fields } & Between groups & 3 & .107 & .036 & \multirow{3}{*}{.168} & \multirow{3}{*}{.918} \\
\hline & Within groups & 309 & 65.742 & .213 & & \\
\hline & Total & 312 & 65.849 & & & \\
\hline
\end{tabular}

Table 7 shows that there are no statistically significant differences at the level of significance $(\alpha=0.05)$ in the sustainable development of the tourism sector in the Palestinian economy based on the variable of the scientific qualification on all the fields of study as well as the total field. The calculated level of significance on all these fields and the total field is above the level of significance specified by the hypothesis. This indicates that there is no difference in views of the respondents attributed to the scientific qualification of the respondents on these fileds and the total field. 
There are no statistically significant differences at the level of significance of $(\alpha=0.05)$ in the sustainable development of the tourism sector in the Palestinian economy based on the gender variable.

In order to test this hypothesis, the mean and standard deviations were calculated for the sustainable development of the tourism sector in the Palestinian economy based on the gender variable. The results showed differences in the averages. In order to examine these differences, the T-test of independent variables and the results are shown in Table 8 below.

Table 8. Results of the T-test for independent samples in the sustainable development of the tourism sector in the Palestinian economy based on gender

\begin{tabular}{|c|c|c|c|c|c|c|}
\hline \multirow[t]{2}{*}{ Field } & \multicolumn{2}{|c|}{ Male $(n=267)$} & \multicolumn{2}{|c|}{ Female $(n=46)$} & \multirow[t]{2}{*}{ T-value } & \multirow{2}{*}{$\begin{array}{l}\text { P value } \\
\text { (Sig.) }\end{array}$} \\
\hline & Mean & $\begin{array}{l}\text { Standard } \\
\text { deviation }\end{array}$ & Mean & $\begin{array}{l}\text { Standard } \\
\text { deviation }\end{array}$ & & \\
\hline $\begin{array}{l}\text { The possibility of investment } \\
\text { in political aspects }\end{array}$ & 3.6011 & .61195 & 3.6793 & 0.51414 & $0.818-$ & 0.414 \\
\hline Promotional quality & 3.5999 & .65514 & 3.6812 & 0.61946 & $0.783-$ & 0.434 \\
\hline General services for tourism & 3.2140 & .71827 & 3.3451 & 0.79808 & $1.125-$ & 0.261 \\
\hline $\begin{array}{l}\text { The obstacles caused by the } \\
\text { Israeli occupation }\end{array}$ & 4.1596 & .63401 & 3.9783 & 0.71084 & 1.759 & 0.08 \\
\hline Total areas & 3.6436 & .46479 & 3.6710 & 0.43093 & $0.372-$ & 0.710 \\
\hline
\end{tabular}

Table 8 shows that there are no statistically significant differences at the level of significance $(\alpha=0.05)$ in the sustainable development of the tourism sector in the Palestinian economy attributed to the gender variable on all fields of study and the total field. The calculated level of significance on these fields and the total field is higher than the level of significance specified by the hypothesis. This indicates that there is no difference in views of respondents based on the sex of the respondent on these areas and the total area.

There are no significant differences at the level of significance $(\alpha=0.05)$ in the sustainable development of the tourism sector in the Palestinian economy attributed to the variable field of work.

In order to test this hypothesis, the means (arithmetical averages) and standard deviations were calculated for the sustainable development of the tourism sector in the Palestinian economy based on the field of work variable. The study results showed that there are differences in the means of the sustainable development of the tourism sector in the Palestinian economy based on field of work. To test whether these differences were statistically significant, One-way Analysis of Variance is used and the results are shown in Table 9 below.

Table 9. Results of one-way analysis of variance for the differences between the means of the sustainable development of the tourism sector in the Palestinian economy based on field of work

\begin{tabular}{|c|c|c|c|c|c|c|}
\hline Variable & Source of variation & $\begin{array}{l}\text { Degrees of } \\
\text { freedom }\end{array}$ & $\begin{array}{l}\text { Differences } \\
\text { squared }\end{array}$ & $\begin{array}{l}\text { Standard } \\
\text { deviation }\end{array}$ & $\begin{array}{l}\mathrm{F} \text {-test } \\
\text { value }\end{array}$ & $\begin{array}{l}\text { P-value } \\
\text { (sig.) }\end{array}$ \\
\hline \multirow{3}{*}{$\begin{array}{l}\text { The possibility of } \\
\text { investment in } \\
\text { political aspects }\end{array}$} & Between groups & 3 & .901 & .300 & \multirow{3}{*}{.837} & \multirow{3}{*}{.474} \\
\hline & Within groups & 309 & 110.848 & .359 & & \\
\hline & Total & 312 & 111.749 & & & \\
\hline \multirow{3}{*}{$\begin{array}{l}\text { Promotional } \\
\text { quality }\end{array}$} & Between groups & 3 & 1.168 & .389 & \multirow{3}{*}{.922} & \multirow{3}{*}{.431} \\
\hline & Within groups & 309 & 130.529 & .422 & & \\
\hline & Total & 312 & 131.697 & & & \\
\hline \multirow{3}{*}{$\begin{array}{l}\text { General Services } \\
\text { for Tourism }\end{array}$} & Between groups & 3 & 2.133 & .711 & \multirow{3}{*}{1.336} & \multirow{3}{*}{.263} \\
\hline & Within groups & 309 & 164.436 & .532 & & \\
\hline & Total & 312 & 166.568 & & & \\
\hline
\end{tabular}




\begin{tabular}{|c|c|c|c|c|c|c|}
\hline \multirow{3}{*}{$\begin{array}{l}\text { The obstacles } \\
\text { caused by the } \\
\text { Israeli occupation }\end{array}$} & Between groups & 3 & .635 & .212 & \multirow{3}{*}{.502} & \multirow{3}{*}{.681} \\
\hline & Within groups & 309 & 130.316 & .422 & & \\
\hline & Total & 312 & 130.951 & & & \\
\hline \multirow[t]{3}{*}{ Total fields } & Between groups & 3 & .409 & .136 & \multirow{3}{*}{644} & \multirow{3}{*}{.587} \\
\hline & Within groups & 309 & 65.440 & .212 & & \\
\hline & Total & 312 & 65.849 & & & \\
\hline
\end{tabular}

Table 9 shows that there are no statistically significant differences at the level of significance $(\alpha=0.05)$ in the sustainable development of the tourism sector in the Palestinian economy based on the variable field of work on all fields of study and the total area. The calculated level of significance on these areas and the total area is above the level of significance specified by the hypothesis. This indicates that there is no difference in views between the respondents according to the field of work on these fields and the total field.

There are no significant differences at the level of significance $(\alpha=0.05)$ in the sustainable development of the tourism sector in the Palestinian economy attributed to years of experience.

In order to test this hypothesis, the means (arithmetical averages) and standard deviations were calculated for the sustainable development of the tourism sector in the Palestinian economy based on years of experience variable. These results showed that there are differences in the means in the sustainable development of the tourism sector in the Palestinian economy based on years of experience. To test whether these differences are statistically significant, one-way analysis of variance was used and the results are shown in Table 10.

Table 10. Results of one-way analysis of variance for the differences between the means of the sustainable development of the tourism sector in the Palestinian economy based on years of experience

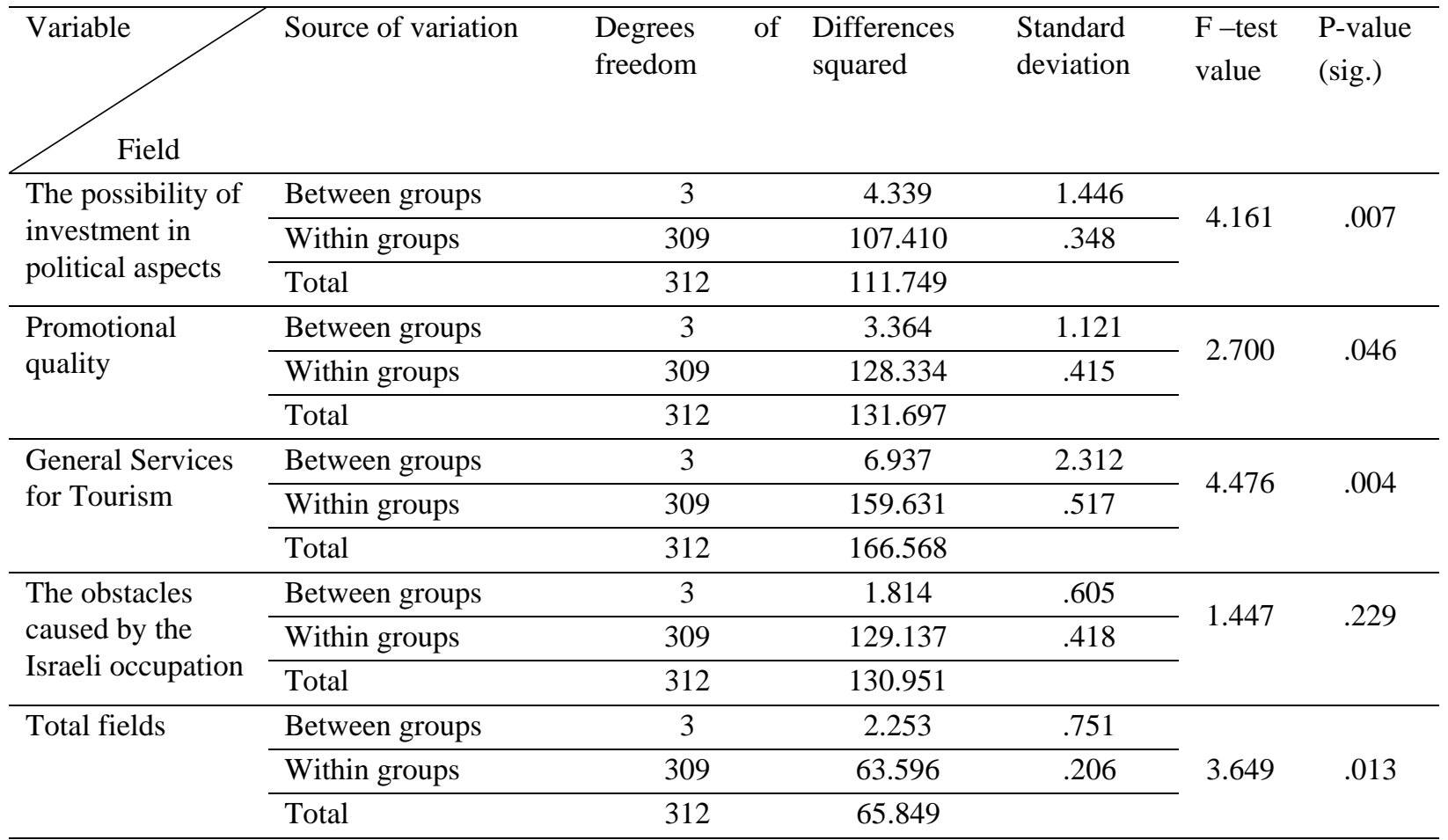

Table 10 shows that there are no statistically significant differences at the level of significance $(\alpha=0.05)$ in the sustainable development of the tourism sector in the Palestinian economy attributed to years of experience mainly in the area of the obstacles caused by the Israeli occupation because the calculated level of significance for this field is higher than the level the significance of the hypothesis. This indicates that there is no difference in the views of the respondents based on years of experience; however, there are differences of statistical significance on each of the 
field of investment potential in the areas of tourism, the field of promotional quality, and the field of public tourism services and the total fields. To identify these differences, the researchers used the LSD and results are shown in Table 11 to illustrate this.

Table 11. Comparisons of years of experience variable

\begin{tabular}{|c|c|c|c|c|}
\hline Field & Years of experience (I) & Years of experience $(\mathrm{J})$ & $\begin{array}{l}\text { Means } \\
\text { differences } \\
(\mathrm{I}-\mathrm{J})\end{array}$ & $\begin{array}{l}P \text { P- } \\
\text { value }\end{array}$ \\
\hline \multirow{2}{*}{$\begin{array}{l}\text { The possibility of } \\
\text { investment in } \\
\text { political aspects }\end{array}$} & Less than 5 years & More than 15 years & $* 0.22396$ & 0.02 \\
\hline & Between 6 to 10 years & More than 15 years & $* 0.31944$ & 0.001 \\
\hline Promotional quality & Between 6 to 10 years & More than 15 years & $* 0.28220$ & 0.005 \\
\hline \multirow{3}{*}{$\begin{array}{l}\text { General services for } \\
\text { tourism }\end{array}$} & Less than 5 years & More than 15 years & $* 0.34444$ & 0.003 \\
\hline & Between 6 to 10 years & More than 15 years & $* 0.36900$ & 0.001 \\
\hline & Between 11 to 15 years & More than 15 years & $* 0.33658$ & 0.007 \\
\hline \multirow[t]{2}{*}{ Total Fields } & Less than 5 years & More than 15 years & $* 0.16277$ & 0.028 \\
\hline & Between 6 to 10 years & More than 15 years & $* 0.22751$ & 0.001 \\
\hline
\end{tabular}

It is clear from the results in Table 11 that the differences were found in the field of potential investment in the tourist areas between the respondents with less than 5 years' experience and the respondents with more than 15 years' experience; there were also differences among the respondents with 6-10 years of experience and those with more than 15 years of experience because the calculated level of significance in these fields is less than (0.05). The study findings also found differences in the field of quality of promotion among respondents with 6-10 years of experience and respondents with experience more than 15 years because the calculated level of significance is $(0.005)$ and this value is less than $(\alpha=0.05)$. Furthermore, the results shown in the table indicated that there are statistically significant differences in the field of general services for tourism among the respondents with less than 5 years of experience, 6-1 0 years of experience, as well as 11-15 years of experience, on the other hand, and among the respondents who have more than 15 years of experience, on the other hand, because the value of the level of significance calculated in these cases is less than $(\alpha=0.05)$. With respect to the total field, the results showed differences among respondents with less than 5 years of experience and respondents with 6-10 years and respondents with over than 15 years of experience.

There are no statistically significant differences at the level of significance $(\alpha=0.05)$ in the sustainable development of the tourism sector in the Palestinian economy attributed to the capital variable

In order to test this hypothesis, the means (arithmetical averages) and standard deviations were calculated for the sustainable development of the tourism sector in the Palestinian economy based on capital. The study results showed that there are differences in the calculated means in the sustainable development of the tourism sector in the Palestinian economy attributed to the capital variable. To test whether these differences are statistically significant, one-way analysis of variance test was used and the results are shown in Table 12 below.

Table 12. Results of one-way analysis of variance for the differences between the means of the sustainable development of the tourism sector in the Palestinian economy based on capital

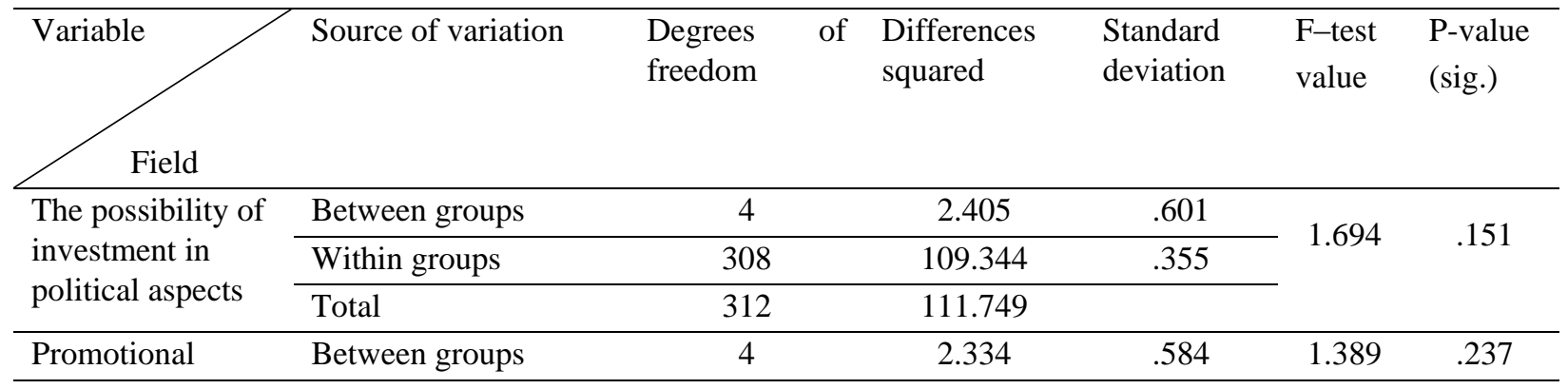




\begin{tabular}{|c|c|c|c|c|c|c|}
\hline \multirow[t]{2}{*}{ quality } & Within groups & 308 & 129.363 & .420 & & \\
\hline & Total & 312 & 131.697 & & & \\
\hline \multirow{3}{*}{$\begin{array}{l}\text { General Services } \\
\text { for Tourism }\end{array}$} & Between groups & 4 & 1.786 & .446 & \multirow{3}{*}{.834} & \multirow{3}{*}{.504} \\
\hline & Within groups & 308 & 164.782 & .535 & & \\
\hline & Total & 312 & 166.568 & & & \\
\hline \multirow{3}{*}{$\begin{array}{l}\text { The obstacles } \\
\text { caused by the } \\
\text { Israeli occupation }\end{array}$} & Between groups & 4 & .928 & .232 & \multirow{3}{*}{.549} & \multirow{3}{*}{.700} \\
\hline & Within groups & 308 & 130.024 & .422 & & \\
\hline & Total & 312 & 130.951 & & & \\
\hline \multirow[t]{3}{*}{ Total fields } & Between groups & 4 & .852 & .213 & \multirow{3}{*}{1.009} & \multirow{3}{*}{.403} \\
\hline & Within groups & 308 & 64.998 & 211 & & \\
\hline & Total & 312 & 65.849 & & & \\
\hline
\end{tabular}

Table 12 shows that there are no statistically significant differences at the level of significance $(\alpha=0.05)$ in the sustainable development of the tourism sector in the Palestinian economy attributed to capital because the calculated level of significance for this field is higher than the level the significance of the hypothesis. This indicates that there is no difference in the views of the respondents based on capital as well as the total field.

There are no statistically significant differences at the level of significance $(\alpha=0.05)$ in the sustainable development of the tourism sector in the Palestinian economy attributed to the number of the labor force variable.

In order to test this hypothesis, the means (arithmetical averages) and standard deviations were calculated for the sustainable development of the tourism sector in the Palestinian economy based on the number of labor force. The study results showed that there are differences in the calculated means in the sustainable development of the tourism sector in the Palestinian economy attributed to the number of labor force variable. To test whether these differences are statistically significant, one way analysis of variance test was used and the results are shown in Table 13 below.

Table 13. Results of one-way analysis of variance for the differences between the means of the sustainable development of the tourism sector in the Palestinian economy based on the number of labor force

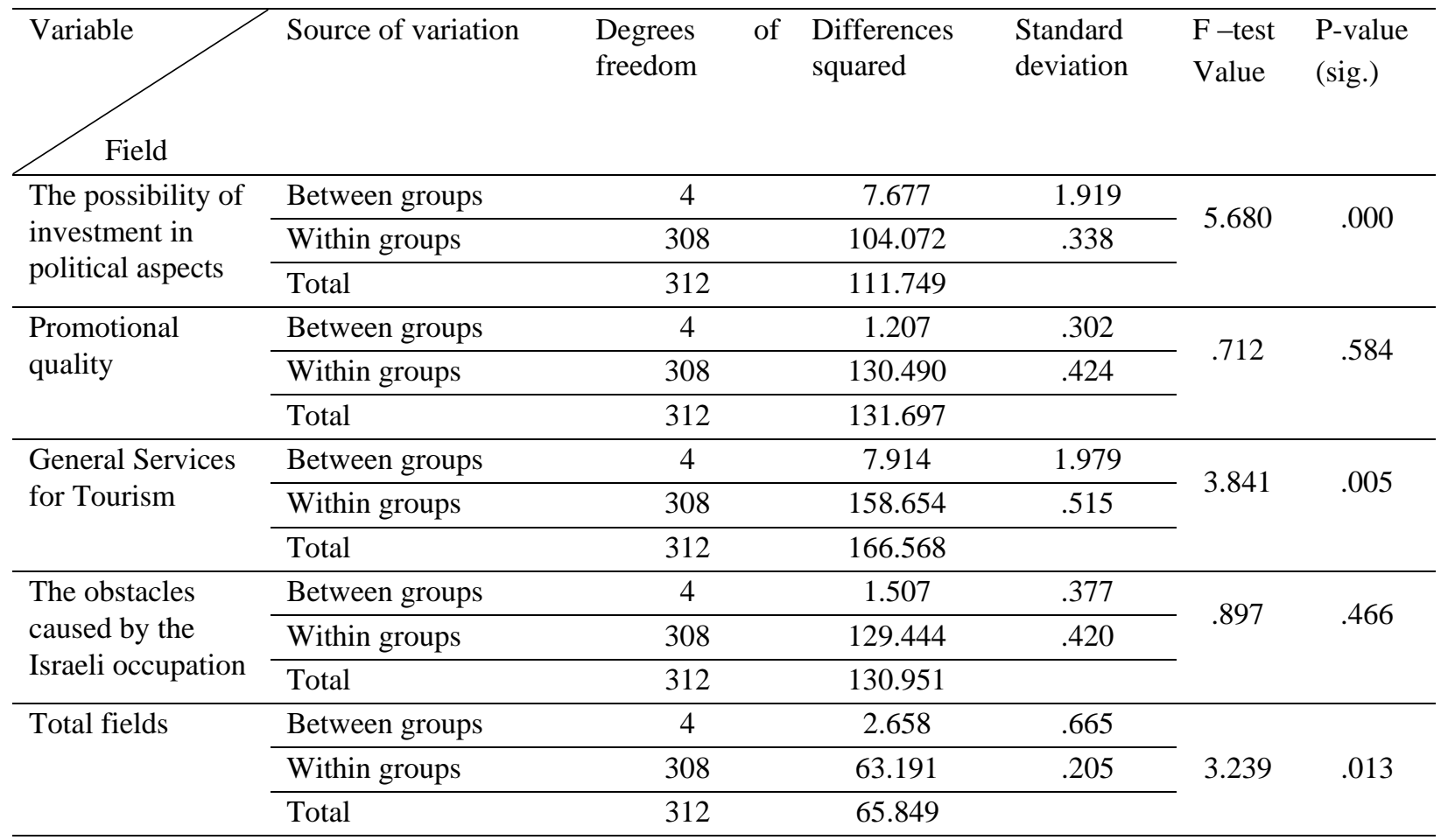


Table 13 shows that there are no statistically significant differences at the level of significance $(\alpha=0.05)$ in the sustainable development of the tourism sector in the Palestinian economy attributed to the number of labor force with respect to quality of promotion and the obstacles caused by the Israeli occupation because the calculated level of significance for these two fields is higher than the level the significance of the hypothesis. However, the study results showed that there are differences in the calculated means in the sustainable development of the tourism sector in the Palestinian economy attributed to the number of the labor force variable with respect to the possibility of investment in political aspects as well as general services for tourism and the total field. To identify these differences, the researchers used the LSD and results are shown in Table 14 to illustrate this.

Table 14. Comparisons of number of labor force variable

\begin{tabular}{|c|c|c|c|c|}
\hline Field & Labor force (I) & Labor force (J) & $\begin{array}{l}\text { Means } \\
\text { differences } \\
\text { (I-J) }\end{array}$ & $\begin{array}{l}\text { P- } \\
\text { value }\end{array}$ \\
\hline \multirow{6}{*}{$\begin{array}{l}\text { The possibility of } \\
\text { investment in } \\
\text { political aspects }\end{array}$} & Less than 10 & Between 12 to 20 & $-.20062^{*}$ & .011 \\
\hline & & Between 21 to 30 & $-.23355^{*}$ & .025 \\
\hline & & Between 31 to 40 & $-.75000^{*}$ & .001 \\
\hline & & More than 40 & $-.48750^{*}$ & .010 \\
\hline & Between 10 to 20 & Between 31 to 40 & $-.54938^{*}$ & .017 \\
\hline & Between 21 to 30 & Between 31 to 40 & $-.51645^{*}$ & .032 \\
\hline \multirow{4}{*}{$\begin{array}{l}\text { General services for } \\
\text { tourism }\end{array}$} & Less than 10 & Between 31 to 40 & $-.92151^{*}$ & .001 \\
\hline & Between 10 to 20 & Between 31 to 40 & $-.75882^{*}$ & 0.008 \\
\hline & Between 21 to 30 & Between 31 to 40 & $-.67857^{*}$ & .022 \\
\hline & Less than 10 & Between 31 to 40 & & \\
\hline \multirow[t]{4}{*}{ Total Fields } & Less than 10 & Between 31 to 40 & $-.46958^{*}$ & .008 \\
\hline & & More than 40 & $-.33892^{*}$ & .022 \\
\hline & Between 10 to 20 & Between 31 to 40 & $-.39333^{*}$ & .028 \\
\hline & Between 21 to 30 & Between 31 to 40 & $-.36931^{*}$ & .048 \\
\hline
\end{tabular}

It is clear from the results in Table 14 that the differences were found in the field of investment potential in tourist areas among the respondents working in tourist establishments whose number is less than 10 workers and the respondents who are working in tourist establishments with a labor force of (10-20), (21-30), (31-40), more than 40 workers as well as in total fields because the level of significance calculated is less than $(\alpha=0.05)$. The results also showed differences on the same field among the respondents working in tourist establishments when the number of workers is (10-20), (21-30) and (31-40) due to the fact that the level of significance is also less than $(\alpha=0.05)$. Differences also emerged in the field of public services for tourism among workers in establishments when the group of workers is less than 10 workers (31-40) workers, (10-20), (21-30), and (31-40) workers on the total area was the differences between workers in establishments with less than 10 Workers and establishments with 31-40 workers as well as establishments with more than 40 workers also showed differences in the same field among workers in establishments with 10-20, 21-30 workers in establishments with 31-40 workers. In all cases, the level of significance Calculated is less than $(\alpha=0.05)$.

There are no significant differences at the level of significance of $(\alpha=0.05)$ in the sustainable development of the tourism sector in the Palestinian economy according to the variable of the governorate.

In order to test this hypothesis, the means (arithmetical averages) and standard deviations were calculated in the sustainable development of the tourism sector in the Palestinian economy based on the governorate. The results showed differences in the averages. In order to examine these differences, t-test was conducted and the results are shown in Table 15 below. 
Table 15. Results of the T-test for independent samples in the sustainable development of the tourism sector in the Palestinian economy based on governorate

\begin{tabular}{|c|c|c|c|c|c|c|}
\hline \multirow[t]{2}{*}{ Field } & \multicolumn{2}{|c|}{ Tulkarm $(n=177)$} & \multicolumn{2}{|c|}{ Jenin $(n=136)$} & \multirow[t]{2}{*}{ T-value } & \multirow{2}{*}{$\begin{array}{l}\text { P value } \\
\text { (Sig.) }\end{array}$} \\
\hline & Mean & $\begin{array}{l}\text { Standard } \\
\text { deviation }\end{array}$ & Mean & $\begin{array}{l}\text { Standard } \\
\text { deviation }\end{array}$ & & \\
\hline $\begin{array}{l}\text { The possibility of investment } \\
\text { in political aspects }\end{array}$ & 3.4647 & .63121 & 3.8051 & .49225 & -5.361 & .000 \\
\hline Promotional quality & 3.5198 & .68194 & 3.7316 & .58625 & -2.893 & .004 \\
\hline General services for tourism & 3.1645 & .72962 & 3.3226 & .72498 & -1.905 & .058 \\
\hline $\begin{array}{l}\text { The obstacles caused by the } \\
\text { Israeli occupation }\end{array}$ & 4.1390 & .62003 & 4.1250 & .68462 & .189 & .850 \\
\hline Total areas & 3.5720 & .49244 & 3.7461 & .39288 & -3.478 & .001 \\
\hline
\end{tabular}

Table 15 shows that there are no statistically significant differences at the level of significance $(=0.05)$ in the sustainable development of the tourism sector in the Palestinian economy attributed to the governorate in both the field of public services for tourism and the obstacles caused by the Israeli occupation. Because the level of significance for these two fields is higher than the level of significance specified by the hypothesis. This indicates that there is no difference in the views between the respondents according to the governorate to which the respondent belongs in these fields; however, the study results found that there are differences of statistical significance at the level of significance $(\alpha=0.05)$ on the field of investment potential in the tourist areas and the field of promotional quality. The level of significance calculated on these fields and the total area is less than $(\alpha=0.05)$ indicating a difference in views between the respondents based on governorate variable.

\section{Results}

The study showed the following results:

Approximately $88 \%$ of the respondents said that the West Bank areas need more investments in the tourism sector

About $82 \%$ of the respondents indicated that the Internet is being used as a means of marketing tourist services

About $90 \%$ of the respondents indicated that Israeli policies at the checkpoints have a negative impact on the tourism movement in Palestine

About $70 \%$ of respondents said that the Palestinian Authority does not benefit from tourists who visit Palestinian tourist locations when arrives through an Israeli office/agency.

The results of the study indicated that there are no statistically significant differences on all fields of the study as well as the total field based on some of the demographic variables including scientific qualification, gender, work, and capital used in tourism.

The results indicated that there are statistically significance differences among respondents based on the governorate variable both on the field of investment potential in tourist places and promotional quality as well as the total field.

The results of the study showed that there are statistically significant differences at the level of significance $(\alpha=0.05)$ attributed to the number of labor force variable both on the field of investment potential in tourism aspects and the field of general services for tourism as well as the total field.

The results of the study showed that there are statistically significant differences at the level of significance $(\alpha=0.05)$ attributed to the years of experience variable both on the field of investment potential in tourism aspects and the field of promotional quality as well as the total field.

\section{Recommendations}

Based on the study results, the researchers recommend the need to:

Increase investment by offering facilities and granting privileges to investors in the tourism sector.

Improve services and increase tourism guidance.

Expand the scope of tourism media and focus on the Internet as a means of marketing tourism in Palestine.

Demonstrate the low tourist cost in Palestine to be an incentive to visit Palestine. 
Work to improve the infrastructure of the tourism sector, and attend its cleanliness and quality.

Work as much as possible to remove the obstacles imposed by the Israeli occupation on tourist areas and locations.

\section{Acknowledgement}

The researchers thank Palestine Technical University- kadoorie for its constant moral and financial support for this research as well as scientific research in general.

\section{References}

Al-Falah, B. (2012). Tourism in the Palestinian Territories: Analysis of Importance and Impact. Palestinian Economic Policy Research Institute (MAS). Retrieved Oct. 2017, from http://www.palestineeconomy.ps/files/server/20151002134741-2.pdf

Ardahaey, F. (2011). Economic Impacts of Tourism Industry. International Journal of Business and Management, 6(8), 206-215. Retrieved from www.ccsenet.org/ijbm

Gozgor, G., \& Ongan, S. (2017). Economic Policy Uncertainty and Tourism Demand: Empirical Evidence from the USA. International Journal of Tourism Research, 19(1), 99-106. Retrieved from https://onlinelibrary.wiley.com/doi/pdf/10.1002/jtr.2089

Hrubcova, G., \& Loster, T., \& Obergruber, P. (2016). The Economic Effects of Tourism in the Group of the Least Developed Countries. Procedia Economics and Finance, 39, 476-481. Retrieved from www.sciencedirect.com

Isik, C., Dogru, T., \& Turk, E. (2017). A nexus of linear and nonlinear relationships between tourism demand, renewable energy consumption, and economic growth: Theory and evidence. International Journal of Tourism Research, 20, 38-49. Retrieved Dec. 2017, from https://onlinelibrary.wiley.com/doi/abs/10.1002/jtr.2151

Paramati, S., Alam, M., \& Chen, C. (2016). The Effects of Tourism on Economic Growth and $\mathrm{CO}_{2}$ Emissions: A Comparison between Developed and Developing Economies. Journal of Travel Research, 56(6). Retrieved Jan. 2018, from http://journals.sagepub.com/doi/abs/10.1177/0047287516667848

Shiji, O. (2016). Economic impact of tourism in India. International Journal of Social Science, 5(1), 35-46. Retrieved from http://ndpublisher.in/admin/issues/IJSSV5N1f.pdf

Zurub, H., Ionesco, A., \& Constantin, V. (2015). Measuring the Economic Impact of Tourism in European Emerging Markets. Emerging Markets Queries in Finance and Business, 32, 95-102. Retrieved from www.sciencedirect.com

\section{Copyrights}

Copyright for this article is retained by the author(s), with first publication rights granted to the journal.

This is an open-access article distributed under the terms and conditions of the Creative Commons Attribution license (http://creativecommons.org/licenses/by/4.0/). 